\title{
MONOPOLY IN PROFESSIONAL SPORTS
}

\author{
JAY H. TOPKIS'̆
}

IN the February 23 issue of The Sporting Neus, baseball's weekly bible, appeared pictures of the late Justice Oliver Wendell Holmes and of Judge Jerome N. Frank. That the pictures were printed could not have surprised most readers. By that time, two weeks after the decision in Gardella v. Chandler, ${ }^{1}$ every baseball fan in the country knew of the controversy that was rocking professional sports. But it must have surprised some to see that in the pictures Justice Holmes looked fierce while Judge Frank looked benign. In the eyes of most of the sports world, Justice Holmes should have worn the look of benevolence, while Judge Frank should have come equipped with horns.

\section{Gardella v. Chandler: The Problem Posed}

Since the case made the front page of even the New York Herald Tribune, ${ }^{2}$ and since most of the legal issues have been well treated elsewhere, ${ }^{3}$ a quick recapitulation should here suffice. In 1945, Danny Gardella was an outfielder on the New York Giants. At the start of the 1946 season, Gardella and the Giant management quarreled. The cause of the quarrel is uncertain. It may have been that Gardella wanted a salary increase. It may have been that his talents were limited. Or, as Gardella claims, it may have been his refusal to wear a necktie. ${ }^{4}$ In any event, Gardella left the Giants and signed for the season with the Mexican League, as did 17 other players from various clubs in the major leagues. ${ }^{5}$ As the migration to Mexico got under way, the High Commissioner of American baseball, Albert B. Chand

† LL.B. Yale Law School, February, 1949.

1. 172 F.2d 402 (1949), reversing, 79 F. Supp. 260 (S.D.N.Y. 1948).

2. N. Y. Herald-Tribune, Feb. 10, 1949, p. 1, col. 2.

3. John Neville's article, Baseball and the Antti-Trust Larus, 16 Foro. L. Rev. $20 \mathrm{~S}$ (1947), has an excellent discussion of the applicability of the federal anti-trust laws to baseball and, impliedly, other professional sports. Johnson, Bascball and the Lan, 73 U.S.L. REv. 252 (1939), discusses the various efforts to enforce baseball contraets. See also Comment, Organtized Baseball and the Larw, 46 Yale L.J. 1396 (1937); Nate, Organized Baseball and the Law, 19 Norre DAsre Law. 262 (1944); Note, Basiball and the Law-Yesterday and Today, 32 V.. L. Rev. 1164 (1946).

4. In a sport never noted for undue decorum or propriety, Gardella was a standout. His greatest escapade involved leaving a suicide note beside an open window in his 12 th floor hotel room. The note blamed his room-mate for his death. While the roommate screamed his remorse, Gardella hung by his hands from the window ledge and, presumably, chuckled softly. Smith, Gardella Hales Baseball into Court, Sports Illustrated, Mar. 1949, p. 10.

5. The Sporting News, Feb. 23, 1949, p. 20, col. 4. 
ler, announced that the migrants would be blacklisted for five years in all leagues under his jurisdiction. ${ }^{6}$

After a season in Mexico, Gardella returned to this country. He sought a job with the Giants and with a number of other clubs in the major and minor leagues. Everywhere, the blacklist was posted and observed. Gardella even claims that teams outside Chandler's jurisdiction would not sign him and that stadium-owners would not allow him on the field for fear of Chandler's wrath. ${ }^{7}$

Gardella sued Chandler, the Giants, the National League, the American League and the president of the minor leagues, alleging that the baseball empire was a monopoly and a conspiracy in restraint of trade, violating both the Sherman and the Clayton Acts. ${ }^{8}$

A somewhat similar action, Federal Baseball Club of Baltimore v. National League, ${ }^{9}$ had been decided in 1922. There, Justice Holmes, speaking for a unanimous Supreme Court, declared that in baseball the important element was the game itself and that a ball game, manifestly, was a local affair, not interstate. Moreover, ". . . personal

6. Under Rule 15 of the Major League Rules, Major-Minor League Rule 15 and National Association Agreement Art. 21, a player becomes "ineligible" automatically by walking out on a reserve clause. As soon as the Commissioner learns of the move, he is required to place the player's name on the "ineligibility list," copies of which are sent to all clubs in organized baseball.

7. Under Rule 15 (a) of the Major League Rules, Rule 15(a) of the Major-Minor League Rules, and Article 21, $\$ 21.01$ of the National Association Agreement, a player who plays in a game with an ineligible player is himself subject to indefinite suspension. For copies of these Rules, see The Basebalz Blue Book, annually published by the Heilbroner Baseball Bureau. The 1948 edition has been used in preparing this article.

In the Lanier-Martin action, infra note 8, an affidavit states: "During the Summer of 1947, with a group of other players who also had sought to better themselves (in Mexico), I toured the United States in an attempt to earn a living at my profession. Wherever we went, agents of the defendants preceded us and threatened owners of bascball parks and players with the direst penalties, including suspension from Organized Baseball for five years if they allowed their teams to play against us or allowed us to use their baseball park." Reprinted from Lewis Burton's column in the N.Y. JournalAmerican, Mar. 12, 1949, p. 12, col. 1-2.

8. 26 Stat. 209 (1890), 15 U.S.C. $\S 1-3$ (1940); 38 Stat. 731 (1914), 15 U.S.C. $\S \S 13-5(1940)$.

Another suit has recently been brought on the same ground by Max Lanicr and Fred Martin, formeriy of the St. Louis Cardinals. While Gardella sceks only $\$ 300,000$, under the Sherman Act's triple damage clause, Lanier and Martin ask $\$ 2,500,000$.

9. 259 U.S. 200 (1922), affirming, 269 Fed. 681 (App. D.C. 1921). This case arose out of the attempt by the Federal League, in 1913-15, to compete as a major leaguc with the National and American Leagues. In 1915, a "Peace Agreement" was signed and all of the Federal League clubs except Baltimore ratified the agreement and dissolved. Baltimore, left with no teams to play against, claimed that the major leagues were responsible and had violated the Sherman Act, $\$ \S 1-2$. A verdict of $\$ 80,000$ was won in the trial court against the two major leagues, their presidents and the chairman of the National Commission. The court of appeals reversed and was sustained by the Supreme Court. 
effort, not related to production, is not a subject of commerce." ${ }^{10}$ Accordingly, since baseball was neither interstate nor commerce, the federal anti-trust laws did not apply.

Behind the screen so erected, baseball and all other professional sports were safe from anti-trust action for twenty-seven years. In the Gardella suit, the district court followed the 1922 precedent and dismissed the complaint for want of jurisdiction. ${ }^{11}$ On appeal, however, the circuit court reversed and remanded by a 2-1 decision.

Judge Chase, dissenting, advanced among others the argument that the Federal Baseball Club case was controlling. ${ }^{12}$ Judge Learned Hand, in one of the two majority opinions, pointed out that since the Holmes decision radio and television had come to play an exceedingly important role in baseball. These activities, he concluded, might "marl the business as a whole" sufficiently to permit regulation by Congress. ${ }^{13}$ In a

10. 259 U.S. 200, 209 (1922).

11. 79 F. Supp. 260 (S.D.N.Y. 1948). Judge Goddard seemed quite reluctant to arrive at his decision. Ibid., passin.

12. Judge Chase also contended that the allegation of restraint on trade d.es not make out a cause of action unless the restraint has or is intended to have an effet on prices in the market or otherwise to deprive purchasers or customers of the effects of competition. Again, he pointed out that there were no allegations in the complaint about indirect effect on price-c.g., on the price of the right to broadeast or advertise.

But the restraint in baseball has a direct effect on the price a player can get for his work. Since he can sell his services to only one buyer, he must accept the buyer's price. And, so far as the Gardella case alone is concerned, see Judge Hand's flat statement that the anti-trust laws "certainly forbid all restraints of trade which were unlawiul at commonlaw, and one of the oldest and best established of these is a contract which unreasonably forbids anyone to practice his calling." 172 F.2d 402, 408 (1949). And see American Medical Ass'n v. United States, 317 U.S. 519 (1943).

13. At the time of the Federal Baseball Club case, 259 U.S. 200 (1922), television was non-existent and radio just beginning. Baseball games were reported by telegraph from each major league park but no advertising was involved. The wire reporting figured in the case only when plaintiff used it to show baseball's great popularity. Id. at 205.

Today, both radio and television are interstate commerce. Communications Act of 1934. 48 Stat. 1064 (1934), 47 U.S.C. $\$ 151$ et seq. (1940). United States v. American Bond and Mortgage Co., 31 F.2d 448 (N.D. Ill. 1929), aff'd., 52 F.2d 318 (7th Cir. 1931), cert. denied, 285 U.S. 538 (1932). Millions of dollars are involved. For the privilege of broadcasting the 1947 World Series, radio paid $\$ 175,000$ and television $\$ 65,000$. N.Y. Herald-Tribune, Oct. 7, 1947, p. 28, col. 5. The Detroit Tigers turned down $\$ 150,000$ for television rights to their 77 home games. Instead, they sold the rights to 35 games (excluding games played on Sundays and holidays) for $\$ 50,000$. The Sporting News, Feb. 23, 1949, p. 24, col. 5. Manifestly, the Detroit management believes that attendance would suffer greatly were weekend and holiday games televised. And the effect of television is being felt even more on minor league citics, where many prople would rather see major league games televised than watch their own teams in the flesh. Largely for that reason, the owners of the Newark, N.J. club considered moving their team at the end of the 1948 season.

The ultimate point will be reached when a nation watches a televised version of 18 
lengthy footnote, Judge Frank, the other member of the majority, wondered whether the Federal Baseball Club case had not been rendered an "impotent zombi" by the Supreme Court's virtual reversal of the precedents on which it relied. ${ }^{14}$ He preferred, however, to distinguish the Holmes decision on the ground advanced by Judge Hand.

Assuming the statements of the complaint to be true, Judge Frank termed baseball ". . . a monopoly which, in its effect on ball-players like the plaintiff, possesses characteristics shockingly repugnant to moral principles . . . basic in America. . . ." Again, he spoke of the players' lot as being "something resembling peonage." 15

To this rough language, the representatives of baseball have answered that the status quo is essential. Without the present stringent system, they contend, baseball could not survive. And, cried Commis* sioner Chandler: "No major leaguer makes less than $\$ 5,000$ a year and some make up to $\$ 100,000$. If you call that peonage, then a lot of us would like to be in on it." 16

Quite possibly, the question of jurisdiction may best be settled after discussion of this argument. If baseball and other professional sportsamong them, hockey and football-must be run along monopolistic lines, perhaps the wisest course is to stick to the Holmes rationale and bar the application of federal law. Since state anti-trust laws do not affect professional sports, ${ }^{17}$ the situation would be saved. No one,

men playing baseball in a stadium converted into a studio, with no spectators present. It would then be hard to say that baseball is a purely local affair. Even with today's imperfect television, it's a safe bet that on lots of weekdays, more people watch games in bars than in bleachers.

If radio and television "mark" baseball as interstate commerce, they blotch hockcy and football pretty much, too.

14. 172 F.2d 402, 409, n. 1. The 1922 decision was largely based on Paul v. Virginia, 8 Wall. 168 (U.S. 1868) and Hooper v. California, 155 U.S. 648 (1895). These cases are almost worthless as precedents in view of United States v. Southeastern Underwriters Ass'n, 322 U.S. 533 (1944) ; cf. Wickard v. Filburn, 317 U.S. 111 (1942). On this point, see Neville, note 3 supra.

15. 172 F.2d 402, 409 (1949). Said Judge Hand: "I do not think that at this stage of the action we should pass upon the reserve clause; and therefore I do not join in my brother Frank's present disposition of it, although I do not mean that I dissent from him." Id. at 408.

16. N.Y. Times, Feb. 10, 1949, p. 39, col. 2. Cf. Judge Frank: "Only the totalitarian-minded will believe that high pay excuses virtual slavery." 172 F.2d 402, 410 (1949). And Red Smith, of the N.Y. Herald-Tribune, referred Commissioner Chandler to "Only a Bird in a Gilded Cage."

17. In most states having anti-trust laws, monopolies, to be illegal, must engage in manufacture, production, transportation, sale or mining of articles or commodities. Sce, e.g., N.Y. Gen. Bus. Law, §340; Ilr. ANn. Stat. (Smith-Hurd, 1935) c. 38, §569; Mass. ANs. Laws (Michie, 1947) c. 93, $\$ 2$. The statutes are construed narrowly. E.g., in Hotel Edison Corp. v. Taylor, 185 Misc. 681, 58 N.Y.S.2d 146 (1944), aff'd without opinion, 268 App. Div. 1029, 52 N.Y.S.2d 941 (1945), aff'd without opinion, 295 N.Y. 581 (1946), the court held that a copyright is an intangible thing, not an article of 
after all, wants to ruin professional sports. And many representatives of the public ${ }^{15}$ and the players ${ }^{19}$ seem quite satisfied with things as they are, monopoly or no. On the other hand, if there are harmful monopolies in professional sports, and the harm can be cured without ruin and woe, professional sports should certainly be forced to comply with the anti-trust laws.

\section{The Organization of Professional Sports}

Nobody in baseball seems to bother denying that the sport is run along monopolistic lines. About the other sports, there has been little discussion. So perhaps the fairest mode of treatment is first to discuss the set-up in baseball and then draw comparisons with hockey and football. ${ }^{20}$

trade or commerce, so a cause of action would not lie against ASCAP for restraining competition in performing rights to musical compositions. But ef. Leader Theatre Corp. v. Randforce Amusement Corp., 186 Misc. 280, 58 N.Y.S.2d 304 (1945), off'd zithou! opinion, 273 App. Div. 844, 76 N.Y.S.2d 846 (1948). In this latter case, there is dicta that where a film copyright, the films themselves, and the right to exhibit them are leased, the anti-trust law does apply. 186 Misc. at 286, 58 N.Y.S.2d at 309. The court distinguished the Hotel Edison case on the ground that there a mere right to perform was leased; here, the court said, the performance itself-the film-was the subject of the contract.

Questionable is the help that would result from passage of a bill introduced in the New York Senate, No. 2270, Int. 2062, Feb. 23, 1949: "Every contract, agreement or arrangement whereby an athlete, player or member of an athletic team is restrained or prevented from negotiating for his services upon the expiration of a contract therefor, without the consent of his employer, is hereby declared to be against public policy and unenforceable"

18. See Editorial, Television and Baseball Peonage, N.Y. Herald-Tribune, Feb. 11, 1949, p. 18, col. 2: ". . . baseball knows best" Consider the weighty words of Rep. A.S. Herlong (D. Fla.) : the Gardella suit ". . . could well sound the death-linell for the sport that has lindled the fires of ambition in the breasts of so many thousands of young Americans." A.J. Liebling, The Wayrard Press, The New Yorker, Mar. 12, 1949, p. 56, 61. Rep. Herlong was once president of a minor league. Mr. Liebling's article is probably the best that will be written on the case.

19. The Chicago Cubs, the Brooklyn Dodgers and the Pittsburgh Pirates have voted their belief that the reserve clause is essential to baseball. N.Y. World-Telegram, Mar. 14, 1949, p. 20, col. 2. N.Y. Daily News, Mar. 18, 1949, p. 83, col. 1-2. No polls have been reported, however, of players on minor league teams.

20. Within the last few years, basketball has reached maturity as a professional sport. The Basketball Association of America has teams in many large eastern cities, and the National League operates in the Mifiddle West. Apparently, however, a number of changes are being made in the basketball scheme, with reference to salary masima, draft systems and agreements among leagues. Letter to the author from Walter Kennedy, Public Relations Director, Basketball Association of America, Mar. 10, 1949. For this reason, I have made no attempt at discussing the sport.

The uniform contract in use in the Association during 1948 gave the club a "right ... to renew ... on the same terms" for another year, with salary cuts limited to $25 \%$. Seemingly, then, this would have the same effect as baseball's reserve clause. 


\section{Baseball}

"Organized baseball" - the term means virtually every team playing a regular schedule and using players who get their living primarily from baseball-is divided into leagues. The leagues are graded according to player caliber. All have banded together to form organized baseball by a series of agreements. The majors are linked by the Major League Agreement, the majors and the minors by the Major-Ninor League Agreement, and the minors by the National Association Agreement. At the top, responsible for the smooth functioning of the combine, is the High Commissioner. ${ }^{21}$

For verbal sanction baseball today depends primarily on the player contract. Without the contract, much the same result could probably be accomplished, for the structure of organized baseball is too strong to require written agreement. But the contract makes everything much easier. ${ }^{22}$

The key feature of the contract is the "reserve clause" by which the club "reserves" the right to sign the player for another year:

21. All player contracts must contain a clause whereby the player recognizes the authority of the High Commissioner. Major League Agreement, Art. 7, §2. The aulthority is virtually unlimited. Probably the most famous use of the Commissioner's powers was the suspension of Leo Durocher for the 1947 season-apparently because Chandler did not like his friends. N.Y. Herald-Tribune, Apr. 10, 1947, p. 1, col. 2.

The agreements submitting to the High Commissioner's authority are apparently enforceable in court. In the only case on the question, Milwauke American Ass'n v. Landis, 49 F.2d 298 (N.D. Ill. 1931), an injunction was sought by the Milwaukce club against Landis, then High Commissioner, to stop him from disapproving a contract assigning a player. Milwaukee's owner had owned several other minor league clubs and, by keeping his ownership secret, had kept a player in the minors longer than was then permitted. Landis investigated and discovered the facts. The court denied the injunction, saying that a question had been submitted to an arbitrator and a decision on such a submission is proper ". . . unless it is unsupported by evidence, or unless the decision is upon some basis without legal foundation or beyond legal recognition." Id. at 303.

Possibly, the Commissioner's actions are subject to attack on the ground that they are part of an illegal conspiracy. See American League Baseball Club of New York v. Pasquel, 188 Misc. 102, 66 N.Y.S.2d 743 (Sup. Ct. 1946) (injunction sought against Mexican League representatives tampering with Yankee players; motion to strike out defense of illegal restraint of trade denied). Cf. Vines v. General Outdoor Advertising Co., 171 F.2d 487 (2d Cir. 1948).

22. Throughout baseball, the contract is apparently uniform, except that the major league contracts do not carry a notice that all contracts must be uniform, while some minor league contracts do. The warning is repeated in Major League Rule 3(a), Major-Minor League Rule 3(a) and National Association Agreement $\$ 15.01$. Major League Rule 3(a) is typical: "To preserve morale and to produce the similarity of conditions necessary to keen competition, the contracts between all clubs and their players in the Major League shall be in a single form which shall be prescribed by the Major League Executive Council. No club shall make a contract different from the uniform contract or a contract containing a non-reserve clause, except with the written approval of the Major League Executive Council." 
"10. (a) On or before February 1st (or if a Sunday, then the next preceding business day) of the year next following the last playing season covered by the contract, the Club may tender to the Player a contract for the term of that year by mailing the same to the Player at his address following his signature hereto, or if none be given, then at his last address of record with the Club. If prior to the March 1 next succeeding said February 1, the Player and the Club have not agreed upon the terms of such contract, then or before 10 days after said March 1 , the Club shall have the right by written notice to the Player at said address to renew this contract for the period of one year on the same terms, except that the amount payable to the Player shall be such as the Club shall fix in said notice; provided, however, that said amount, if fixed by a Major League Club, shall be an amount payable at a rate not less than $75 \%$ of the rate stipulated for the preceding year.

(b) The Club's right to renew this contract, as provided in subparagraph (a) of this paragraph 10, and the promise of the Player not to play otherwise than with the Club have been taken into consideration in determining the amount payable under paragraph 2 hereof." 23

On its face, the contract is for one year, ${ }^{24}$ with an option of renewal for another year. Seemingly, the player is free at the end of the second year to deal with any other team. In many cases, this would be tremendously profitable for the player. Any number of players on good teams ride the bench at low salaries when, by shifting to poorer teams, they could be first-stringers at higher pay. ${ }^{25}$ Again, many great players work for poor clubs when they could command far higher salaries from the wealthier teams. ${ }^{26}$

The fact, however, is that they do not shift. Throughout "organized

23. Reprinted from The Sporting News, Feb. 23, 1949, p. 10, col. 4-5, p. 20, cül. 1-2. This is the contract used since the 1947 season. It does not speak of any "right of reservation" in the club as did the former contract. But the effect is still the same. The old contract is also printed in The Sporting News.

24. The contract may, of course, be for more than one year. But at the end of whatever period the contract covers, the reserve clause comes into effect.

25. Red Smith suggested, for example, that Stan Rojck, of the Brooklyn Dodgers, could get a $\$ 20,000$ bonus from the Chicago Cubs or the Philadelphia Phillies for signing, were he not bound to Brooklyn by the reserve clause. N.Y. Herald-Tribune, Feb. 12, 1949, p. 15, col. 2. Rojek was subsequently sold to the Pittsburgh Pirates for well over $\$ 20,000$, but the sale price went to Broollyn, not to Rojel:

26. Arthur Daley wrote in the N.Y. Times: "Admittedly the reserve clause can and has worked hardships in individual cases. Walter Johnson toilcd long and faithfully for Clark Griffith when he could have made ten times as much money for Col. Jacob Ruppert's Yankees. Certainly those things happen. . . But isn't life itself filled with such instances?" Replied A. J. Liebling: "I could not help admiring the stoicism with which Mr. Daley accepted Johnson's misfortune; I don't suppose the late Washington pitcher lost more than half a million dollars because of his club affiliation, anyway. There are some newspapermen I know who would resent working all their lives on one 
baseball" a player signs a new contract containing the above clause each year. It's impossible to tell why this is so. Perhaps the players realize that no other team would deal with them. Perhaps the clubs make clear to their players that they must sign a new contract or not play. ${ }^{27}$ And perhaps no player, in a world filled with lawyers, has ever had the idea suggested to him.

The result, then, is that what appears to be a contract for one year is a contract for life. At the start of each season, the player cannot shop around to see who will pay the most for his services. He knows that he must work for one employer. Usually, his only lever for in. creasing his pay is the owner's fear that the player will be unhappy over his salary and will play badly. In some rare instances, with topflight stars like Joe DiMaggio and Ted Williams, the owner may fear an unfavorable public reaction if he pays his star poorly.

Everyone recognizes everyone else's contracts with players. Even were a player with one club to jump his contract-and face whatever legal action might be brought ${ }^{28}$ - he could not play for any other club.

paper for one-tenth of what they could get on another, and I feel ashamed for them." Liebling, note 18 supra, at 60 .

27. This may be officially admitted, depending on the interpretation given Major League Rule 3(d): "Any agreement between club and player for service, evidenced by" written acceptance, whether by letter or telegram, or receipt from player for moncy advanced to him to bind such agreement, shall be construed to be a contract and held to be binding, provided the player declines to enter into a formal contract; but his refusal to sign such formal contract shall render him disqualified to play with the contracting club or to enter the service of any Major or Minor League Clubs unless released or assigned."

Under the Major-Minor League Rules, a player apparently must sign a contract before playing-and this covers players in the major leagues as well as the minors. "All players shall upon or before reporting for duty sign the standard form of contract adopted by the Major League Executive Council or the President of the National Association...." Rule 3(c). A similar provision appears in the National Association Agreement, § 15.03 .

Even if a player could avoid the effect of the reserve clause by staying out of baseball for a year, he could not afford to, for his playing life is too short. Among the 640 players on major league rosters at the start of the current season, only 44 had been in the majors for ten years. This includes time spent in the armed forces. The Sporting News, Mar. 9, p. 18, col. 1.

28. To protect themselves in still another way, the clubs have inserted the following provision in the uniform contract:

"4. (a) The Player represents and agrees that he has exceptional and unique skill and ability as a baseball player; that his services to be rendered hereunder are of a special, unusual and extraordinary character which gives them peculiar value which cannot be reasonably or adequately compensated for in damages at law, and that the Player's breach of this contract will cause the Club great and irreparable injury and damage. The Player agrees that, in addition to other remedies, the Club shall be cntitled to injunctive and other equitable relief to prevent a breach ... . including the right to enjoin the Player from playing baseball for any other gerson or organization 
They would have no part of him..$^{29}$ Every once in a while, of course, an "outlaw" outfit like the Mexican League comes along. But, thanks to the blacklist, jumping to an outlaw team is professionally equal to jumping out of a window.

The result is a complete absence of equality in bargaining position. Taking advantage of this, most of the minor leagues impose upper limits on salaries. In Class D leagues, for example, no club may have a total payroll of more than $\$ 2600$ monthly. Since the club is also limited to a maximum of 16 or 17 players, the average player receives around $\$ 155$ monthly. ${ }^{30}$

Player contracts are assignable- even when the season is over and the only control that the club has over a player is the reserve clause. So transfer of players from league to league is simple. Many clubs high up in the hierarchy own or have "working agreements" with clubs in inferior leagues. The lower clubs, or "farms," train players until they are good enough for the big time and then send them on up. In return, they receive aged veterans, youngsters for further seasoning, and regular sums of cash. ${ }^{31}$ Through the farm system, the major league clubs

during the term of this contract." The poor record of the clubs in obtaining injunctive relief is reviewed in Johnson, Bascball and the Law, 73 U.S. L. Rev. 252 (1939).

29. Under Major League Rule 15, any player who jumps his contract or the reserve clause is automatically ineligible, and no club may permit him to play. See MajorMinor League Rule 15; National Association Agreement Art. 21.

30. These were effective during the 1948 season. The player limit changes during the season, the clubs usually being allowed more players at the beginning and end than during the height of the campaign. The lower class leagues make their sules by class; the higher leagues act individually. The major leagues have no salary limits.

For Class D leagues, during the height of the season, the player limit is usually 16 or 17. Other figures are:

$\begin{array}{lcc} & \begin{array}{c}\text { Player Limit } \\ \text { (mid-season) }\end{array} & \begin{array}{c}\text { Maximum Afonthly } \\ \text { Payroll }\end{array} \\ \text { Class A1 } & 18-19 & \$ 7,000 \\ \text { Class A } & 18-19 & 5,400 \\ \text { Class B } & 17 & 4,000 \\ \text { Class C } & 17 & 3,400 \\ \text { Class D } & 16-17 & 2,600 \\ \text { Class E } & 17 & 750\end{array}$

For exact information on each league, see The Baseball Blte Book.

31. On the joys of life in a farm system: "I was in the Giant farm system. I don't think the average minor-league manager is interested in anything but his own advancement. I've seen, in my travels, managers use hids like cattle, pitch their arms off, and when they had dead wings, ship them home and hire another chump. You can always get crazy kids to fill those uniforms. . . . I look back at a lot of dirty rooming houses and undigested meals (just try to live on $\$ 100 \mathrm{a}$ month) and realize it did me a lot of good. The glamor wore off. Now I'm ready to work hard at anything for a decent paycheck, a clean, permanent home, and not have to live over the railroad tracks. ..." Statement of George Luginsland to Jimmy Powers, N.X. Daily News, Mar. 11, 1949, p. 17, col. 4-5. 
control around $90 \%$ of the nation's ball players. ${ }^{32}$

It is on the farms that the reserve clause works most perniciously. Players who could be of use to clubs higher in the hierarchy-and who could there get higher salaries-are often kept in inferior leagues for the convenience of the clubs owning their contracts. True, there are restrictions on how long a man may be kept in the various league classifications, ${ }^{33}$ but they are far from being totally effective. Far too often, the test of the league a man plays in and the salary he gets is the needs of his owner, not the player's abilities.

Some minor league clubs operate independently, develop youngsters for the major league clubs and then sell their contracts. During the 'thirties, scarcely a year passed when the San Francisco team did not have one member of the DiMaggio family up for sale.

When players are sold, whether from the minors to the majors or from one major league club to another, the entire sale price goes to the club. Sometimes, a portion is turned over to the player, but this happens very rarely. Quite often, in consequence, a player with two or three years of baseball life remaining is sold for a price far higher than his salary will be during the years he will work.

It would be unjust to say that the club-owners exploit their position to the maximum. They do not. But much of what has been given to the players is yielded under pressure. The greatest gains for the players came three years ago when Mexican League representatives were outside every locker room, waving certified checks. The major league owners forthwith adopted a salary minimum $(\$ 5,000)$, a limitation on salary cuts (no more than $25 \%$ under the preceding year's figure), a pension fund and a player-representation plan. ${ }^{34}$

These are merely self-imposed limitations on power that is absolute. As they have been given, so may they be taken away. They do not diminish the fact that the player is confronted with an absolute monopoly. If he wants to play baseball, it must be on the monopoly's terms. From the moment that he signs his first contract, the price that he will receive for his work, the conditions of work and the place he will work are determined by the monopoly. That occasionally some-

32. Dan Parker's column, The Broadway Bugle, N.Y. Mirror, Mar. 14, 1949, p. 27. Parker suggests that some major league ownership is concealed. In this connection, sct Milwaukee American Ass'n v. Landis, 49 F.2d 298 (N.D. Ill. 1931).

33. Broadly speaking, the rules permit a major league team to keep a player in the minors for around four years. After that, the major league club must either put him on its own roster or allow another major league club to deal with him. The player does not, however, have the opportunity to solicit competitive bids for his services. Sec Major League Rule 5, Major-Minor League Agreement Art. VI, National Association Agreement Art. 27.

34. The granting of these benefits also coincided with the attempt by the American Baseball Guild to unionize a number of major league clubs. See p. $711 \mathrm{infra.}$ 
thing like the Mexican League crops up does not detract from the restraint.

If competition is the life of trade, baseball has attempted suicide. ${ }^{35}$

The monopoly does not affect only the players. It also prevents any change in the way the major league and many of the minor league clubs are distributed. There is little logic in the present distribution of major league teams. St. Louis and Boston, together, have four clubs. Detroit, with a population greater than the other two combined, has one. Los Angeles, which on a population basis should have three or four major league clubs if Cincinnati has one, has none. This distribution made sense fifty years ago when the leagues were formed. Transportation was then a factor. But today Los Angeles is no farther than Chicago from Boston, if planes, rather than trains, are used. The professional football teams fly regularly. So do many of the minor league baseball clubs. And even the majors have, on occasion.

The barrier is not fear of flying.

Rather, the majors are afraid to disturb a system that is, on the whole, quite profitable. ${ }^{36}$ The result is that new teams of major league caliber cannot be started and existing franchises cannot be moved to other cities. These are not absolute rules. Major League Rule 1(c) states:

"To preserve and stimulate competition for the League Pennants and for the World Championship, the circuits thus established shall remain unchanged either by withdrawal from a city, by inclusion of another city or by consolidation of clubs within a city, unless in any case the change is approved by a majority of clubs in each League, except that the circuit of either Major League shall not be changed except by the unanimous consent of the clubs constituting said League."

Although the above provision for change exists, there has been no change since the early years of the present century. Time after time,

35. Note, however, that the clubs still do compete in some ways. See p. $707 \mathrm{infra}$.

36. "Sam Breadon once was said to have offered Walter $O$. Briggs, Sr., a cool million to let the Cardinals share the Detroit park with the Tigers. But Briggs refused to talk business. If he had entertained the proposition, the rest of the American League would have voted him down. Take that from William Harridge (president of the American League) who should know. Transfer of the Cardinals to Detroit would be a tremendous benefit to the National League, and would help to solve the Browns' problcm, as well. But it just isn't happening." Dan Daniel's column, N.Y. World-Tclegram, June 6, 1947, p. 29, col. 5 .

Some clubs occasionally lose money, of course. But astute management and clever promoting can turn club coffers into little replicas of Fort Knos. Reportedly, Leland Stanford MacPhail made $\$ 2,000,000$ with the Yankees in three years, while Robert Hannegan turned a quick million dollar profit by holding his interest in the Cardinals for only a year. N.Y. Daily News, Mir. 8, 1949, p. 17, col. 4-5; N.Y. World-Telegram, Mar. 22, 1949, p. 30, col. 1-2. 
groups have petitioned for new franchises or have been formed to buy and move existing clubs-but the necessary permission has never been obtained. Like many another unchallenged institution, baseball is the victim of self-imposed paralysis.

About the only way that major league clubs could be set up in cities that deserve but don't have them would be by forming a new league. That is financially impossible. Of the many attempts made to form a new circuit-the last, by the Federal League in 1913-15-only one, by the American League in 1903, succeeded. And that was in baseball's infancy as a vast business enterprise. Today, millions would be needed for the effort. And, in the face of opposition from the entrenched resources of organized baseball-and its stranglehold on almost all of the talent ${ }^{37}$ - the effort would be certain to fail.

A New York court thirty-five years ago described baseball in words that require no change today:

"It is apparent from the analysis already set forth of the agreement and rules forming the combination of the baseball business, referred to as 'organized baseball'; that a monopoly of baseball as a business has been ingeniously devised and created in so far as a monopoly can be created among free men." ${ }^{38}$

\section{Ice Hockey ${ }^{39}$}

More closely than any other sport, professional ice hockey parallels the practices developed in baseball. There are a multitude of leagues, mostly in Canada, all affiliated with each other by contract. At the top of the pyramid is the National Hockey League.

No position exists, however, analogous to that of baseball's High Commissioner. Responsibility for the enforcement of contracts rests with the president of each league. Under the Standard Player's Contract employed by the National League, "The Player . . . undertakes that he will at the request of the Club enter into a contract for the following playing season upon the same terms and conditions as this contract save as to salary which shall be determined by mutual agreement." This proviso has the same effect as baseball's reserve clause. As in baseball, the player annually must sign a new contract with the same old clause. There is, however, one important difference. "In the event that the Player and the Club do not agree upon the salary to be paid the matter shall be referred to the President of the League, and the parties agree to accept his decision as final." Base-

37. Note that the reason that a rival league could be started in football, sce p. 705-6 infra, is that in football the colleges steadily furnish a supply of fresh talent.

38. American League Baseball Club v. Chase, 86 Misc. 441, 149 N.Y.S. 6 (Sup. Ct. 1914).

39. For the information on the National Hockey League, $\mathrm{I}$ am indebted to $\mathrm{Mr}$. Clarence S. Campbell, president of the league. 
ball's Major League Rule, by contrast, flatly provides that salary disputes are not to be referred to the Commissioner.

The hockey teams have farm systems similar to those of baseball. Indeed, the farms are frequently amateur clubs, for there exists in hockey a definition of amateurism not found elsewhere in American sports.

In the National League, at least, there is neither an individual nor a club salary limit. No minimum provision exists officially, but the president of the league has authority to approve or disapprove salaries. During the past three years, no contract has been approved where the salary was not at least $\$ 5,000$ for the season.

\section{Football 40}

For twenty years, the National Football League was the only major football league operating. Three years ago, however, its dominance was challenged by a new organization, the All-America Conference. The battle has been lengthy and costly to both sides.

At the start of the fight, the Conference busily signed dozens of established National League stars. Reserve clauses went by the board. ${ }^{41}$ After the mass raid, however, the leagues settled down and, so far as can be ascertained, have not since attempted to deal with each other's players.

Both leagues use uniform player's contracts, enforced by league commissioners. Under the National League contract, ${ }^{42}$ the club retains an option of renewal for one year at the salary for the year covered by the contract. The option is effective until May 1. On its face, the contract states that ". . . after such renewal this contract shall not include a further option to the Club to renew the contract." In theory, then, at least, the player may serve out the year on the option and then look elsewhere for a job. Equally, where a club attempts to cut a player's salary, he is apparently free to leave. In practice, however, football follows baseball. At the beginning of each season a player is forced to sign a new contract. He never avails himself of the golden opportunities which theory offers him. Probably, he knows quite well that none of the other clubs in the league would deal with him were he to break the established pattern. So the option agreement becomes a lifetime tie.

40. A copy of the All-America Conference standard contract was bindly supplied by the Conference's counsel, Willkie, Owen, Farr, Gallagher and Walton.

41. Not all NFL players signing Conference contracts did so in violation of options, however. A great many men went into the armed services from NFL teams and, on returning to civilian life, went directly to the AAC.

42. The National League and All-America Conference contracts, lilie those used in hockey and baseball, contain stipulations by the player that he is of unique slill and that, in consequence, the club is entitled to injunctive relief against breach. 
In the Conference uniform contract, the club until June 1 ". . . may renew this contract for said following year on the same terms, including the terms of payment, . . . unless Player and Club agree upon a higher or lower payment to Player." "Any dispute between Player and Club shall be referred to the Commissioner as an arbitrator and the Commissioner's decision shall be accepted by all parties as final." Whether these two sections are read together, I have been unable to learn. In any event the normal practice, as in the National League, is that the players annually sign new contracts. Again, the probable explanation is that there would be no hope of other employment. Certainly a number of men now employed by Conference teams would be unable to return to the National League, for a blacklist was there posted much like the one Commissioner Chandler used in baseball during the Mexican invasion.

Although player sales among clubs in each league are commonplace, there has been little attempt to develop farm systems. Minor leagues exist, but their dealings with the two dominant organizations are few. The reason, of course, is that the colleges supply the great bulk of professional football players. ${ }^{43}$ The clubs do not, however, bid competitively for the services of the new men. Each league has an annual "draft" during which the teams deal out among themselves the right to bargain with specific players. ${ }^{44}$ Quite often, a man is drafted by a club in each league and the competition becomes stiff.

Player salaries have been driven up by the fight. A recent estimate is that the average salary has gone from $\$ 4,000$ to $\$ 8,000$ in the threeyear war. ${ }^{45}$ The club owners of the two leagues have made repeated efforts at merger. The hope is at least to set up a common draft, so as to eliminate competition for players. Even further amalgamation would probably be welcomed.

But none of the efforts has been successful. All of the clubs have lost money-at least on their own say-so. ${ }^{46}$ The obstacle to ending competition is apparently the question of which clubs shall be forced out completely and forced to swallow their losses, and which ones will will go on to fatten in the peace that will follow.

43. This article does not cover professionalism in college sports. But it is interesting to note that when colleges seek football players of talent they bid against each other in the open market. There have been no open complaints, at least, that competitive bidding is ruining the game. Note, however, that once a man signs-or matriculates-with a college, he is not free to transfer at the end of any season. Most college leagues have rules that make a man ineligible for varsity sports for one year after a transfer.

44. At the end of the 1948 season, each team in the NFL received draft rights on 25 men. Rarely would a team want to look over more new men than that.

45. Time, Jan. 3, 1949, p. 31, col. 1.

46. Estimates vary with the affiliation of the official estimating. Arthur McBride, owner of the Cleveland Browns of the All-America Conference, claimed that the $\mathrm{Na}$ tional League lost $\$ 1,093,000$ in 1948 while the Conference dropped only $\$ 725,000$. 
One result of the war has been that cities which never before had professional football now have clubs. Throughout the twenty-five year history of well-organized professional football, franchises have moved around regularly. Within the last three years, the shifting has accelerated. It is now pretty apparent that Boston and Brooklyn are football pest-holes. ${ }^{47}$ Miami did not stir up any great enthusiasm over the sport. But San Francisco and Los Angeles, the two cities major league baseball would rather forget, are at least good football possibilities. And Green Bay, Wis. (pop. 46,235) can make top-light ball profitable at least a couple of times yearly. ${ }^{43}$ The significance is that in football for the first time in recent years in professional sports, there is an opportunity for competition to settle the question of where the big time really does belong.

\section{Predictions of Ruin}

As an understatement, it's safe to say that professional sports are shot through with monopolistic elements. ${ }^{49}$ In baseball, the most extreme example, the monopoly drives down the players' wages and thwarts any change in the distribution of clubs. In hockey, much the same is evidently true so far as the players are concerned. And while it is hard to appraise whether the right cities have the major league clubs-hockey is apparently an acquired taste-the odds are that a new league would have little chance of survival in the face of the tightly-knit existing organization. The players get a slightly better break in football. Coming out of college, they often have two clubs bidding for their services. But no more than two-the leagues malee sure of that. And, once a man signs, he deals with the same club for the balance of his career, unless his contract is sold, On the credit side for football, chalk up the fact that a new league is not doomed to failure.

47. Before the war, Boston had a representative in the National League. Afiter suffering losses even with championship teams, the owner, George P. MFarshall, moved the franchise to Washington. After the war, another National League club was set up there, but after three years of losses the team has now moved to New Yorl:. The AllAmerica Conference wisely stayed out of Boston.

Brooklyn has had an entry in both the National League and the Confercnee, at different times. Both failed. At the end of last season, the Conference team was merged with the New York franchise.

48. The Green Bay Packers, one of the earliest and more consistently successiul teams in the National League, split their home dates between Green Bay and Milwaulsce.

49. The monopoly may well exercise its power in fields not here diseussed. For esample: "No Major League club shall consent to or authorize a broadcast or telcast (including rebroadcast or network broadcast) of any of its games to be made from a station outside its 'home territory' and within the 'home territory' of any other baseball club, MIajor or Minor, without the consent of such other bascball elub." MIajor League Rule 1 (d) (2). "Home territory" extends fifty miles from the center of the ball park. For a description of the rule in operation, and a suggestion that the Anti-Trust Division may be interested, see The Sporting News, Dec. 29, 1948, p. 10, col. 1-2. 
Millions are needed, and dozens of scouts to beat the bushes for talentbut the talent is available, and, if the money is forthcoming, the venture can succeed.

If the test of unrestrained competition is applied to professional sports, most of their restrictive tactics will have to go. This will mean an end to the system symbolized by the reserve clause. Mere removal of the clause from contracts will not, of course, do the trick. Affirmative action-regular and steady competition among the clubs for playersis the only true satisfaction of the test.

To the suggestion that free competition be made the law of professional sports, the defenders of the status quo have two answers. First, they cry that the reserve clause system is necessary because otherwise the wealthier clubs would hire all the best players and competitionon the field-would vanish. A corollary is that the financial competition would ruin everyone. The other point made is that the minor league clubs would perish-this, it is argued, would be unfortunate since the minors do make baseball available to small towns and, as well, furnish a steady flow of experienced players to the majors.

A number of answers are available to the threat of a decline in competition. For the sake of simplicity, I will mention them in terms of baseball, but to a greater or lesser extent they apply as well to the other sports.

Probably the best answer is that-despite the reserve clause-the wealthy clubs dominate the game today. The teams that spend money on players are the teams that wind up high in the league standings. ${ }^{60}$ Some clubs put their money into direct player purchases, buying from the minors and the poorer clubs in the majors. Others develop extensive minor league connections. The Yankees, the Boston Red Sox, the Dodgers ${ }^{51}$-and, when fresh money was poured in, the Pittsburgh Pirates, the Boston Braves and the Philadelphia Phillies-

50. A survey of the pennant races during the last thirty years furnishes corroboration. In that period, in the American League, the Yankees finished worse than third just twice. Fifteen times they won the pennant. The St. Louis Browns, on the other hand, finished better than fourth just seven times-and three of those times were war years when anything could happen. The Chicago White Sox finished better than fourth five times.

In the National League, during the same period, the St. Louis Cardinals finished worse than third only nine times and won nine pennants. The Boston Braves, on the other hand, until 1946, never finished better than fourth. In 1947, they wound up third and last year won the pennant. New ownership, with cash to spend, had taken over.

51. The Yankees began spending heavily when Col. Jacob Ruppert bought most of Boston's top-ranking stars-among them, Babe Ruth-during the 'twenties. When Tom Yawkey took over the Red Sox in the 'thirties, he reestablished the team as a pennant threat by going into the market and paying top prices for players. The Dodgers became a team, rather than a subject for humorous anecdote, when L. S. MacPhail loosened the purse-strings. 
all have done well by spending large sums of cash. Altruism was not involved. When fans know that their local club-owners are spending heavily on a team, they eagerly support it. The return in increased attendance usually over-compensates for the expenditure on players. By contrast, the teams that have done poorly in recent years-among them the Washington Senators, the St. Louis Browns and the Chicago White Sox-have pretty much been coasting on their franchises. Their owners apparently realize that an irreducible minimum of spectators will always congregate at a baseball game. So on small gate receipts, low salaries and regular player sales, the owners manage to subsist.

The clubs which are really pennant-hungry often break out into the open in their search for players. Boys who make sizable reputations in high school, college or American Legion competition are regularly pursued by major league representatives, all armed heavily with cash. As soon as their names go on contracts, the boys are caught for life, but they often manage to make the catching a costly business. In a number of recent cases, bonuses for signing have gone as high as $\$ 50,000.52$ The clubs endeavor to limit this practice by a set of intricate rules. ${ }^{53}$ But the race for talent goes on.

All this is nothing other than competition with the brakes on. The clubs which want to fight for the lead do so-with cash. And the owners who want no part of the struggle sit by, content with more meager rewards. The present set-up boils down, then, to two points: first, competition is made fairly cheap for everyone; second, anyone who does not want to compete need not do so. Wealth struggles for dominance, and the reserve clause allows the poorer clubs to keep running.

In this light, the dire predictions of an end to competition on the diamond and the onset of ruinous pocketbook rivalry seem rather bizarre. A more likely possibility is that the end of the present system would see healthy competition on all fronts throughout the leagues. Only the clubs that made money by having good teams and being successful at the box-office would be able to survive. A number of franchises would probably have to be moved. With the protection of the reserve clause gone, moving or folding would be the only two courses open to some of the weaklings. One of New York's better, if bitter, sportswriters put it well: "If taking the reserve clause out of the con-

52. Rennie, The Bonus Rule Plagues Baseball, Sports Illustrated, Mareh, 1949, p. 18.

53. The over-all effect of the rules is that the club signing the player must lieep him on its squad if it has paid him a bonus of more than a fixed sum. For major league clubs, the figure is $\$ 6,000$. For the rules, see Miajor League "Bonus Rule," MrajorMinor League Rule 3 (F) (1), National Association Agreement Art. 15, \&\$ 15.06-07.

Rennie, note 52 supra, claims that the rules often ruin players in that they ride the bench in higher leagues when they could be gaining needed experience in slower competition. 
tract would mean that the parasitic clubs that have been living off the richer ones would have to fold up, baseball would be much better off." 54

Admittedly, it is not fair to assume that in an era of free competition the clubs would all have absolutely equal financial resources-even on the further assumption that only cities capable of supporting teams would have them. But in baseball, as perhaps elsewhere, money isn't everything. Baseball history is full of stories of high-priced flops. Branch Rickey, formerly of the St. Louis Cardinals and now president of the Dodgers, has become notorious as a peddler of sore-armed pitchers and arthritic outfielders to his wealthier and gullible confreres. ${ }^{55}$ On the other hand, Connie Mack, of the Philadelphia Athletics, manages to piece together a top-flight club every fifteen years or so by careful investment of nickels and dimes and large admixtures of baseball skill. Mr. Rickey has used the same prescription effectively. And there is still another reason why with free competition no one club would buy up all the talent and spread-eagle the field: baseball magnates are not fools. If anyone got together a group of perfect players, who would pay to see them play the other teams in the league? Everyone will try hard to assemble perfect teams. But not too perfect. There would be no money in it.

Still another possibility is open. A competing major league would have in its path none of the obstacles now set up by the monopoly features of organized baseball. With agreement general that players would work for whoever paid them the most, organized baseball would be able to post no blacklists nor employ any other coercive tactics. True, the initial financial outlay would be large. But there would be a chance of success where today there is none. ${ }^{56}$

The end-product would probably be, for the first time in forty years, a distribution of high-quality baseball among the cities that want it and are able to pay. True, there would doubtless be at least a brief period of uncertain competition, as some clubs bid more for players than their incomes warrant. The three year football war furnishes proof that this can be fairly costly. But in football the war goes onand it is doubtful that the men fighting it believe heartily in throwing

54. Dan Parker, in N.Y. Daily Mirror, Feb. 11, 1949, p. 42, col. 1-2.

55. Rickey's most famous transaction was the sale that sent Dizzy Dean to the Chicago Cubs for $\$ 185,000$. With the Cardinals, Dean" was "the greatest pitcher who ever lived, not counting days I was sick." With the Cubs, he showed that he would become the fine radio announcer he now is.

56. The defense of the reserve clause is even less effective when applied solely to fights between organized baseball and "outlaw" leagues. Such was the situation in the Gardella case. Even assuming that the reserve clause is warranted to promote competition within the two major leagues, that point is not here relevant. Gardella's departure did not result in one team's getting an advantage over the others. The only defense for the blacklist then can be that it is needed to prevent ruinous competition between leagues. Standing all by itself, the argument looks awfully weak. 
good money after bad. Shrewd management does not for very long permit costs to outrun income. Every business, after all, has the problem of speculating on its receipts as a means of setting allowable costs. Why exempt sports?

Most important, the players would at last be paid in accordance with the market's estimate of their abilities. In football, the onset of a minimum of competition has reportedly doubled players' salaries. Doubtless this gain will not be entirely retained, for there is probably some-although not complete-correlation between football's high salaries and high losses. ${ }^{57}$ But certainly this experience, coupled with baseball's extremely healthy present financial situation, indicates that a substantial increase in salaries will follow introduction of competition. ${ }^{58}$

This effect may, however, be limited to the major and the higherranking minor leagues. Many teams in the lower leagues today fail to show a profit on gate receipts alone. Far more do they depend on the subsidies they receive as farms and on their sales of players. Assuming that these two sources of income would be cut off by the end of the monopoly system (if there were no reserve clause, player contracts could not be sent up so cash would not come down) it seems reasonable to predict that many minor league teams would have even less money available for salaries than they do today. Salaries would consequently tumble.

The story is not, however, quite that simple. Today, a lot of small cities have teams by way of gift. The majors funnel down funds to keep the teams going and the teams send up players. The cities which do not support the teams nonetheless get to see them play. Actually, the gift does not come from the major league clubs. They charge it off as player expense. If the money did not go to the farms, it would or could go to the players. So the gift is actually from the players on the teams higher up in the hierarchy. Since the bulk of the players in the major leagues earn between $\$ 5,000$ and $\$ 10,000$ yearly during their short professional life, it seems unreasonable to ask them to contribute large sums to either a benevolent fund for their less skilled colleagues or to a Fund for the Exhibition of Baseball in Small Cities in the United States. A bright note, then, in killing the monopoly system, is that there would be even more money available for salaries in the higher minor and major leagues.

Nor need salaries necessarily plummet throughout the lower minor

57. Unwise competition for attendance has probably been the major cause of loss. In New York, for example, there were three teams last year and this year a fourth is moving in. In Chicago, the AAC for three years has tried unsuccessiully to compete with the two National League teams.

58. The last three seasons have seen all previous attendance records smashed in the major leagues. Wornd Alrianac 829 (1949). 
leagues. It seems doubtful that they could fall much lower than they are today in the Class $D$ and $E$ leagues. Few men would play for less than the wage rates now there prevailing. So for Class D and E cities, at least, there might be a choice between supporting their teams and not having them. Probably, a lot of teams would fold. The number might well be smaller than an auditor of the books would expect, however. When the cities were faced with the choice between supporting their teams and not having them, civic response might change substantially. And where civic organizations strongly backed their local teams, free competition for players might put strong upward pressure on wages. In the intermediate leagues, some decline in salaries must be expected. But not too much, for there baseball begins to support itself. And civic pride might often fill the gap. Where it failed, the players might well be reconciled by the imminence of their graduation to the high paying majors.

The over-all result might be a fairly substantial rewrite of the present baseball map, but not a complete collapse of baseball as it is today. The lower leagues would be thinned out. But a thinning-out seems almost inevitable today regardless of what is done about the monopoly. As television enters all homes, the experience in Newark, N. J., last year is likely to become common. There, the local team suffered a sharp drop in attendance, largely attributable to the citizens' ability to sit in bars and watch the Yankees, Giants and Dodgers play. The Newark owners considered moving their franchise, but decided to wait at least another year before taking action. If that happened in a city of the International League, where baseball is just one cut below the majors, more cataclysmic results are probable farther down the scale.

In the thinning-out, the character of baseball may well change. Teams may again become local affairs, instead of local arms of a corporation in a far off city. A home town boy may even make the squad.

This sort of set-up would not prevent a regular movement upward as a player became more experienced. Because of the fewer number of professional teams, there would be fewer players available, but ccrtainly there would always be sufficient to fill the ranks of the major league clubs. The difference would be that bargaining, rather than monopoly position, would determine how often a player moved and at what salary levels.

If the shortage of skilled talent became serious, nothing would bar the major league clubs from taxing themselves for a general support fund for minor league baseball. An intermediate remedy, an assignable player contract covering more than one year, would also be available, so long as its use did not develop into a wage-depressing conspiracy. True, these remedies would likely diminish the players' part of the spectator's dollar. But to the extent that the players had bargaining 
power, the cost of any intermediate remedies would be borne by the owners.

\section{Other Possible Remedies}

Competition seems to offer far more than it threatens. But since it is-as opposed to monopoly - an extreme course, fairness requires consideration of any feasible alternatives. The two most obvious intermediate paths, however-arbitration and unionization-do not seem fruitful.

Hockey practice suggests the first possible intermediate course. There, the player and the club are not isolated in their discussion of salary. The National League president is named arbitrator by the contract of any dispute. The St. Louis Cardinals-the players-have recommended a similar rule for baseball. ${ }^{59}$ The immediate objection to the hockey practice is that the league president (named by the clubowners), is not likely to be totally impartial. Even the Cardinal proposal of an impartial board of arbitrators-presumably setting salaries throughout the sport-is not wholly satisfactory. First, it does nothing about the present barriers in the way of new leagues. With all the player talent tied up, and all of the existing leagues aligned solidly, a new league would have small chance of survival. Second, the arbitrators would be unlikely to force the shifting of present franchises that is desperately needed in baseball and at least possibly desirable in football and hockey. An arbitrator's function, after all, is to do equal justice to both sides-and the arbitrator is rare who would wilfully bankrupt one side, no matter how well merited the bankruptcy. The result would probably be that player salaries would be kept below the level they could attain were teams properly distributed. Possibly, governmental arbitration could meet this objection, but permanent intervention by the Federal Government hardly seems desirable before competition-which promises so much-is tried.

A second possible solution, establishment of strong players' unions, also has substantial drawbacks. Practically, it is extremely unlikely. Professional athletes evidently just do not want to organize. ${ }^{\circ} \mathrm{On}$ a number of occasions, attempts have been made in baseball to organize the players, but success has not been lasting. The latest try was in 1946, when an outfit known as the American Baseball Guild endeavored to organize the Pittsburgh Pirates, the Yankees, the Dodgers and the Giants. In an election run by the Pennsylvania Labor Relations Board,

59. N.Y. Daily News, Mar. 14 , 1949, p. 45 , col. 1.

60. Possibly, were professional sports to be declared interstate commerce, the players would organize more readily under the aegis of the National Labor Relations Board than they have under state law. The NLRB three years ago refused to talie jurisdiction of a baseball labor controversy on the ground that it did not involve interstate commerce. Brief on Jurisdiction, Case No. 83, Penna. Lab. Rels. Bd. (1946). 
the Pirates spurned the Guild by a vote of $15-3^{61}$ and the campaign collapsed.62 Even were sport-wide unionization successful, however, it would not facilitate the development of new leagues nor would it be likely to force the shifting of present franchises.

Somewhere between the extremes there may be some other method of operation that would solve professional sport's problems. But there is little need to grope desperately for one. Letting free competition rule does not seem particularly dangerous. It may have some regrettable consequences but they are likely to be nowhere nearly so harmful as is the present system.

The Anti-Trust Division has announced that it is watching the Gardella case carefully.63 Presumably, it will move if the courts find that baseball is interstate commerce. ${ }^{64}$ That finding seems entirely desirable. For the defense of the current order comes down to the warning that "Daddy knows best." ${ }_{55}$ That is not a valid reason for hamstringing legislation on a subject which Congress thought it knew pretty well. ${ }^{66}$ (1946).

61. Note, Baseball and the Laz-Yesterday and Today, 32 VA. L. REv. 1164 n. 1

62. N.Y. Times, June 10, 1947, p. 34; col. 5.

63. In 1937, the Attorney-General ruled that the Department of Justice could not investigate baseball because of the court ruling that baseball is not interstate commerce. N.Y. Times, Apr. 15, 1937, p. 25, col. 2. Last February, however, the Department announced that if the Gardella suit should "result in a court holding that Organized Baseball is interstate commerce, we would certainly be interested in studying the decision." N.Y. Daily Mirror, Feb. 17, 1949.

64. In addition to possible action by the Anti-Trust Division if baseball is interstate commerce and a monopoly exists, every man who played last year theoretically has a cause of action for the difference between the salary he received and the sum he would have received had the restraint not existed. An individual or a class action would secmingly be appropriate. But the presentation of proof would be extremcly difficult.

65. "It is the history of monopolies in this country and in England that predictions of ruin are habitually made by them when it is attempted, by legislation, to restrain thir operations and to protect the public against their exactions." Northern Securities Co. v. United States, 193 U.S. 197, 351 (1904); approved in United States v. Southeastern Underwriters Ass'n, 322 U.S. 533, 561 (1944).

66. The move to make professional sports safe for monopoly seems to be shifting from the courts to Congress. A bill has been introduced by Representative Herlong (see note 18 supra) to insulate organized professional sports from the anti-trust laws. H.R. 4019, 81st Cong., 1st Sess. (1949). 